Jeff James P. Alega, MD

Emmanuel Tadeus S. Cruz, MD

Department of Otorhinolaryngology

Head and Neck Surgery

Quezon City General Hospital
Correspondence: Dr. Emmanuel Tadeus S. Cruz Department of Otorhinolaryngology

Head and Neck Surgery

Quezon City General Hospital

Seminary Rd., Bgy. Bahay Toro, Quezon City 1106

Philippines

Phone: (+632) 88630800 local 40

Email: orl_hns_qcgh@yahoo.com.ph

The authors declared that this represents original materia that is not being considered for publication or has not been published or accepted for publication elsewhere in full or in part, in print or electronic media; that the requirements for authorship have been met by all the authors, and that each author believes that the manuscript represents honest work.

Disclosures: The authors signed a disclosure that there are no financial or other (including personal) relationships, intellectual passion, political or religious beliefs, and institutional affiliations that might lead to a conflict of interest.

Presented at the Philippine Society of Otolaryngology Head and Neck Surgery COVID-19 Research Forum 2020 (2nd Place), Nov $18,2020$.

\section{Association of Anosmia and Positive SARS-CoV-2 (COVID-19) RT-PCR Test Results Among Patients in the Quezon City General Hospital}

\begin{abstract}
Objective: To determine the association of anosmia and positive SARS-CoV-2 (COVID-19) RT-PCR test results among patients in a tertiary government hospital in Metro Manila.
\end{abstract}

\section{Methods:}

\section{Design: Cross-Sectional Study \\ Setting: $\quad$ Tertiary Government Training Hospital}

Participants: Patients aged 18 years old and above who consulted or were admitted with COVID-19 symptoms at the Quezon City General Hospital in the Philippines from July to September 2020 answered an offline version of the American Academy of Otolaryngology - Head and Neck Surgery AAO-HNS COVID-19 Anosmia Reporting Tool prior to undergoing (COVID-19) RT-PCR testing.

Results: Out of 172 participants, 63 (36.6\%) presented with anosmia. Sixty (95.2\%) out of 63 of those with anosmia had a positive COVID-19 RT-PCR test result. Forty-one (65\%) participants reported anosmia as the first symptom while the most common associated symptoms were fever (59\%), cough (50\%), and rhinorrhea (31\%). There was a significant association between anosmia and positive SARS-CoV-2 (COVID-19) RT-PCR tests ( $\left.\mathrm{X}^{2}=33.85, \mathrm{df}=1, \mathrm{p}<.0001\right)$. A significantly higher proportion of patients with anosmia were positive for COVID-19 than those without anosmia at 95.2\% and 52.3\% respectively. The risk for COVID-19 among patients with anosmia was almost two times higher than those without anosmia ( $R R=1.82 ; 95 \% C l: 1.51-2.20 ; p<.0001)$.

Conclusion: Anosmia was associated with a positive SARS-CoV-2 (COVID-19) RT-PCR test in more than $95 \%$ of those who reported the symptom. Anosmia should be considered as a red flag sign which should be included in the screening of persons suspected of being infected with COVID-19 to help mitigate further spread of the virus.

Keywords: anosmia; olfactory dysfunction; Ioss of sense of smell; coronavirus; SARS-CoV-2; pandemic; 2019-NCoV; COVID-19

According to the Johns Hopkins University Coronavirus Resource Center, there have been 33.4 million cases of the coronavirus disease (COVID-19) globally with over 1 million deaths recorded worldwide as of this writing. ${ }^{1}$ The World Health Organization has reported 33.2 


\section{ORIGINAL ARTICLES}

million cases with over 999,000 deaths recorded. ${ }^{2}$ In the Philippines, there were 309,303 confirmed cases and 5,448 deaths by the end of September 2020 with the National Capital Region consistently having the most number of COVID-19 positive individuals. ${ }^{3}$ Transmission has been increasing at an exponential rate, and early detection and prompt testing are crucial to control the spread of the disease.

Various studies have shown that apart from fever, cough, and dyspnea, anosmia (loss of sense of smell) is an early symptom that may have a role in screening for COVID-19. ${ }^{46}$ Lechien and colleagues showed that $85.6 \%$ of COVID-19 cases presented with olfactory dysfunction. ${ }^{4}$ Another study showed that $11.8 \%$ of patients reported anosmia early in the course of the disease preceding other clinical manifestations. ${ }^{5}$ The American Academy of Otolaryngology-Head and Neck Surgery (AAOHNS) released the initial findings of the COVID-19 Anosmia Reporting Tool (https://www.entnet.org/content/reporting-tool-patients-anosmiarelated-covid-19) that reported anosmia was observed in $73 \%$ of cases prior to diagnosis and that $26.6 \%$ of patients reported anosmia as their initial symptom. ${ }^{6}$ In the absence of local studies, this study was initiated to establish a basis for using anosmia as a possible early screening symptom to identify patients with COVID-19 in our setting.

The objective of this study was to determine the association of anosmia and positive SARS-CoV-2 (COVID-19) RT-PCR tests among patients in our tertiary hospital in Metro Manila.

\section{METHODS}

This cross-sectional study was approved by the Planning, Development, Education and Research Office / Hospital Training Office of the Quezon City General Hospital.

All patients (including healthcare workers) aged 18 years old and above with COVID-19 symptoms such as cough, fever, and difficulty of breathing who consulted and/or were admitted in the Quezon City General Hospital from July to September 2020 were considered for inclusion. Excluded were those with nasal problems (sinusitis, nasal mass, nasal polyps, nasopharyngeal cancer, history of nasal trauma), pre-existing olfactory dysfunction, and those with altered states of consciousness or who were in cardiorespiratory distress and were not able to understand and answer the COVID-19 Anosmia Reporting Tool.

The sample size was computed using a $95 \%$ level of confidence and $80 \%$ power of the study. With an estimated proportion of patients with loss of smell among those positive and negative for COVID-19 of $59.41 \%$ and $18.97 \%$, respectively. Based on the study by Menni et al., at least 19 patients per group was needed. A 20\% allowance was added to come up with at least 23 patients per group.

$n=\frac{\left[z \alpha \sqrt{2 p q}+z \beta \sqrt{P 1 Q 1+P 2 Q^{2}}\right]^{2}}{(P 1-P 2)^{2}}, p=\frac{\left(P_{1}+P_{2}\right)}{2} \quad q=1-p$
Where:

$$
\begin{aligned}
& \mathrm{n}=\text { is the number of subjects needed } \\
& \mathrm{P} 1=\text { proportion of patients with loss of taste and smell among } \\
& \quad \text { those COVID- } 19(+)= \\
& =59.41 \%=0.5941 \\
& \mathrm{Q} 1=1-\mathrm{P} 1=1-0.5941=0.4059 \\
& \mathrm{P} 2=\text { proportion of patients with loss of taste and smell among } \\
& \quad \text { those COVID-19 }(-)= \\
& =18.97 \%=0.1897 \\
& \mathrm{Q} 2=1-\mathrm{P} 2=1-0.1897=0.8103 \\
& \mathrm{p}=(\mathrm{P} 1+\mathrm{P} 2) / 2=0.3919 \\
& \mathrm{q}=1-\mathrm{P}=1-0.3919=0.6081 \\
& \mathrm{Za}=95 \% \text { confidence level }=1.96 \\
& \mathrm{Z} \beta=80 \% \text { power of the study }=1.28
\end{aligned}
$$

Informed consent was obtained prior to inclusion, and enrolled participants were administered a bilingual version of the AAO-HNS COVID-19 Anosmia Reporting Tool prior to undergoing the COVID-19 RT-PCR swab test. (Figure 1) Permission to utilize an offline bilingual version of the tool was obtained from the AAO-HNS Anosmia Team. Participants were assisted in accomplishing the reporting tool if they had questions or clarifications. The AAO-HNS created the COVID-19 Anosmia Reporting Tool for Clinicians in March 2020 and published it online with the purpose of acquiring data from healthcare providers around the world to serve as a database for emerging data on COVID-19 related anosmia. ${ }^{6}$ Experts from the AAO-HNS Infectious Disease and Patient Safety and Quality Improvement Committees developed this tool, ensuring adequate face validity. The bilingual study version of this tool was not validated, as the Filipino annotations were only added without changing the English elements.

After answering the questionnaire, participants underwent COVID-19 RT-PCR swab test using one of the following testing kits, depending on the institution to which the specimens were sent: GenAmplify ${ }^{\text {TM }}$ COVID-19 rRT-PCR Detection Kit (Manila HealthTek, Inc., Marikina, Philippines), Sansure Biotech Inc. 2019-nCov Nucleic AcidBased Diagnostic Reagent Kit, PCR-Flourescence Probing (Hunan, People's Republic of China), or the genesig Real-Time PCR Coronavirus COVID-19 (CE IVD) Kit (Chandler's Ford, UK). Specimens at the time were sent to Department of Health (DOH) - approved testing facilities such as Philippine Genome Center, Chinese General Hospital and Medical Center, and St. Luke's Medical Center. Per hospital protocol, the COVID-19 RT-PCR test results were retrieved by the QCGH Department of Pathology for documentation and safe-keeping, and copies of results were sent to those tested through e-mail with printed copies sent to the concerned outpatient clinic or in-patient ward for admitted patients. The clinic or ward copies were those accessed for this study. 
ORIGINAL ARTICLES

Responses were tabulated and collated using MS Excel for Mac version 16.13 (Microsoft Corporation, Redmond, WA, USA). Participants with incompletely accomplished COVID-19 Anosmia Tool for Clinicians and those whose RT-PCR tests turned out "Invalid" (due to insufficient specimen collection) were further excluded from the study.

STATA 13.1 (StataCorp LLC, College Station, TX, USA) was used for data analysis. Descriptive statistics were used to summarize the demographic characteristics of participants. Frequencies and proportions were used for categorical variables and mean and SD for normally distributed continuous variables. The independent Sample T-test and Chi-square test were used to determine the difference of mean and frequency between patients with and without COVID-19, respectively. Relative risk and corresponding $95 \%$ confidence intervals were computed to determine the association of anosmia and COVID-19. Null hypotheses were rejected at 0.05 a-level of significance.

\section{RESULTS}

A total of 172 participants suspected of COVID-19 infection who underwent RT-PCR test were included in the study. One hundred seventeen (68\%) were positive for COVID-19 while 55 (32\%) were negative. Ages ranged from 19 to 88 years with a mean of 42.55 years. Almost $53 \%$ were $\leq 40$ years old. Using independent t-test, there was a significant difference in the age of patients who were positive and negative for COVID-19 $(t=3.79, d f=170, p=<.001)$. The age of patients positive for COVID-19 was significantly higher than those with negative results, with a mean of 45.58 years and 36.12 years respectively. There were 81 (47.1\%) males and 91 (52.9\%) females. Sixty-one out of 81 (75.3\%) and 56 out of 81 (61.5\%) were RT-PCR positive for males and females respectively. There was a significant difference in the proportion of males and females with or without COVID-19 $\left(X^{2}=3.74, d f=1_{L} p=.05\right)$.

Using chi-square test, there was a significant association between anosmia and SARS-CoV-2 RT-PCR (COVID-19) test results ( $X^{2}=33.85$, $d f=1, p<.0001)$. A significantly higher proportion of patients with anosmia were positive for COVID-19 than those without anosmia at 95.2\% and 52.3\% respectively. The risk for COVID-19 among patients with anosmia was almost two times higher than those without anosmia $(R R=1.82 ; 95 \% C l: 1.51-2.20 ; p<.0001)$.

Out of 172 patients included in the study, 63 (36.6\%) reported having anosmia and all of these manifested prior to diagnosis. Sixty (51.2\%) out of 117 COVID-19 positive individuals reported loss of smell as one of their symptoms. Anosmia was the first symptom in $41(65 \%)$ of these patients. For the $22(34.9 \%)$ patients who had other symptoms prior to onset of anosmia, the most common were fever (59\%), cough (50\%), and rhinorrhea (31\%). Of the 63 patients with anosmia, 60 (95.2\%) had a positive COVID-19 RT-PCR test result while $3(4.7 \%)$ were negative.

\section{DISCUSSION}

The study showed that there was a significant association between anosmia and positive COVID-19 RT-PCR test results. More than 50\% of diagnosed COVID-19 patients in the present study presented with anosmia. In the literature, the incidence of anosmia varies from a low

\begin{tabular}{|c|c|c|c|c|c|c|c|c|}
\hline \multirow{2}{*}{\multicolumn{9}{|c|}{$\begin{array}{l}\text { COVID-19 ANOSMIA REPORTI } \\
\text { 1. Medical Specialty of Submitting Provider. (If patient, enter "self"). } \\
\text { Kung pasyente, ilagay ang "sarili". }\end{array}$}} \\
\hline & & & & & & & & \\
\hline \multirow[t]{2}{*}{$\begin{array}{l}\text { 2. Patient Age } \\
\text { Edad }\end{array}$} & \multicolumn{2}{|c|}{$\begin{array}{l}\text { 3. Patient Gender } \\
\text { Kasarian }\end{array}$} & \multicolumn{3}{|c|}{$\begin{array}{l}\text { 4. Patient location at time of } \\
\text { diagnosis } \\
\text { Lokasyon }\end{array}$} & \multicolumn{3}{|c|}{$\begin{array}{l}\text { 5. What is the COVID status of the patient } \\
\text { Estado ng COVID infection ng pasyente }\end{array}$} \\
\hline & \multicolumn{2}{|c|}{$\begin{array}{l}\square \text { Male (Lalaki) } \\
\square \text { Female (Babae) }\end{array}$} & \multicolumn{3}{|c|}{$\begin{array}{l}\square \text { United States } \\
\square \text { Others (lba pa) }\end{array}$} & \multicolumn{3}{|c|}{ 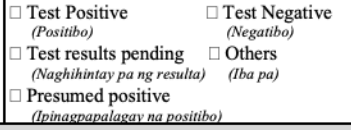 } \\
\hline \multicolumn{3}{|c|}{$\begin{array}{l}\text { 6. Is the source of the COVID-19 } \\
\text { infection identifiable? } \\
\text { Alam ba kung saan nanggaling ang } \\
\text { impeksyon? }\end{array}$} & \multicolumn{6}{|c|}{$\begin{array}{l}\text { 7. Please list any risk factors for COVID-19 infection present. } \\
\text { Pilin ang mga risk factor para mahawa sa COVID-19 }\end{array}$} \\
\hline $\begin{array}{l}\square \text { Yes }(O o) \\
\square \text { No (Hindi) }\end{array}$ & & & 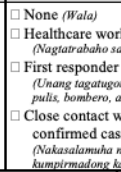 & 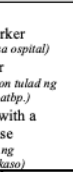 & $\begin{array}{l}\square \text { Hom } \\
\square \text { Cong } \\
\text { Maa } \\
\square \text { Trav } \\
\text { tran } \\
\square \text { Othe }\end{array}$ & $\begin{array}{l}\text { ess (Walang } \\
\text { esant livin } \\
\text { ming kasama } \\
\text { to known } \\
\text { nission } / G \\
\text { lba pa) }\end{array}$ & $\begin{array}{l}\text { "gg tirahan) } \\
\text { ng (dorms, } \\
\text { "a sa tirahan } \\
\text { areas wit: } \\
\text { Galling sa lug }\end{array}$ & 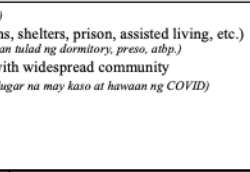 \\
\hline $\begin{array}{l}\text { 8. Other risk fac } \\
\text { Iba pang mga } r\end{array}$ & $\begin{array}{l}\text { etors/co } \\
\text { skfactor }\end{array}$ & $\begin{array}{l}\text { morbidities } \\
\text { karamdaman }\end{array}$ & & $\begin{array}{l}\text { 9. When } \\
\text { sense } \\
\text { (altera } \\
\text { first nu } \\
\text { Kailan } \\
\text { pang-ar }\end{array}$ & $\begin{array}{l}\text { was the } \\
\text { of smell) } \\
\text { tion of sc } \\
\text { ticed by } \\
\text { nagsimula }\end{array}$ & $\begin{array}{l}\text { nosmia }(l \\
\text { ordyseu } \\
\text { sse of tast } \\
\text { he patien } \\
\text { me paxkaw }\end{array}$ & $\begin{array}{l}\text { loss of } \\
\text { usia } \\
\text { ste) } \\
\text { nt? } \\
\text { vala ng }\end{array}$ & $\begin{array}{l}\text { 10. Did the patient have any } \\
\text { other symptoms BEFORE } \\
\text { the development of } \\
\text { anosmia/dysgeusia? } \\
\text { Nagkaroon ba nu ibang sintomas } \\
\text { bago sa pagkawala ng pang- } \\
\text { amoy? }\end{array}$ \\
\hline $\begin{array}{l}\square \text { None (Wala) } \\
\square \text { Smoking Nanining } \\
\square \text { Head trauma } \\
\quad \text { Naaksidente sa ulo, } \\
\square \text { Sinusitis/Allergy } \\
\text { (Sakitis sa sinus at all }\end{array}$ & & 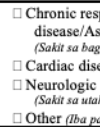 & $\begin{array}{l}\text { piratory } \\
\text { sthma } \\
\text { shahila) } \\
\text { ease (Sakit sa puso) } \\
\text { disease } \\
\text { dis at mga ugat) } \\
\text { a) }\end{array}$ & $\begin{array}{r}\text { Before } \\
\text { (Bago } \\
\text { After } \\
\text { (Matap }\end{array}$ & $\begin{array}{l}\text { diagno } \\
\text { nakumpir } \\
\text { tiagnosi } \\
\text { os makum }\end{array}$ & $\begin{array}{l}\text { is } \\
\text { ang kaso) } \\
\text { irmang ka }\end{array}$ & & $\begin{array}{l}\square \text { Yes (Oo) } \\
\square \text { No (Hindi) }\end{array}$ \\
\hline $\begin{array}{l}\text { 11. What symp } \\
\text { AT THE T } \\
\text { Ano pang iban } \\
\text { pagkawala ng }\end{array}$ & $\begin{array}{l}\text { toms di } \\
\text { IME of } \\
\text { ig sintom } \\
\text { pang-am }\end{array}$ & $\begin{array}{l}\text { id the patient } \\
\text { anosmia/dys } \\
\text { as ang meron ke } \\
\text { noy? }\end{array}$ & $\begin{array}{l}\text { thave } \\
\text { sgeusia? } \\
\text { a KASABAYng }\end{array}$ & $\begin{array}{l}\text { 12. Wha } \\
\text { COV } \\
\text { time } \\
\text { was } \\
\text { Ano } \\
\text { mazk } \\
\text { pang }\end{array}$ & $\begin{array}{l}\text { t was the } \\
\text { ID-19 ir } \\
\text { the anos } \\
\text { observed } \\
\text { me kundis } \\
\text { aroon ka } \\
\text { amoy? }\end{array}$ & $\begin{array}{l}\text { condition } \\
\text { eection at } \\
\text { ia/dysge } \\
\text { nom mo nan } \\
\text { papkawal }\end{array}$ & $\begin{array}{l}\text { n of the } \\
t \text { the } \\
\text { eusia } \\
\text { la ng }\end{array}$ & $\begin{array}{l}\text { 13. Did the patient's condition } \\
\text { worsen or improve after the } \\
\text { anosmialdysgeusia was } \\
\text { observed? } \\
\text { Lumala ba bumuti ang kundisyon } \\
\text { mo matapos mawalan n\& pang- } \\
\text { amoy? }\end{array}$ \\
\hline $\begin{array}{l}\square \text { None (Wala) } \\
\square \text { Fever (Lagnat) } \\
\square \text { Chills (Panginginig } \\
\square \text { Malaise, fatigue } \\
\text { (Panghihina ag kataw } \\
\square \text { Cough (Ubo) }\end{array}$ & anpagod) & $\begin{array}{l}\square \text { Headache } \\
\square \text { Nasal conge } \\
\text { (Pagbabara } n_{8} \\
\square \text { Rhinorrhea, } \\
\text { (Sinisipon) } \\
\square \text { Gastrointest } \\
\text { (Pagsakit ng } \\
\square \text { Other } \text { (biba pe }\end{array}$ & 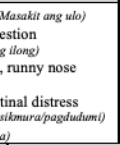 & $\begin{array}{r}\text { Inpatic } \\
\text { (Naka- } \\
\text { Outpa } \\
\text { (Napau }\end{array}$ & $\begin{array}{l}\text { ent/hosp } \\
\text { admit sa c } \\
\text { tient } \\
\text { wi) }\end{array}$ & pilized & & $\begin{array}{l}\square \text { Worsen (Lumala) } \\
\square \text { Improve (Bumuti) }\end{array}$ \\
\hline $\begin{array}{l}\text { 14. What is the } \\
\text { COVID-19 } \\
\text { Ano ang kasal } \\
\text { impeksyon ng }\end{array}$ & $\begin{array}{l}\text { patient } \\
\text { infectic } \\
\text { ukuyang } \\
\text { pasvente }\end{array}$ & $\begin{array}{l}\text { t's current } \\
\text { on status? } \\
\text { estado ng }\end{array}$ & $\begin{array}{l}\text { 15. Did the a } \\
\text { resolve? } \\
\text { Bumuti ba }\end{array}$ & $\begin{array}{l}\text { anosmia/d } \\
\text { ang pagkaw }\end{array}$ & $\begin{array}{l}\text { ysgeusi } \\
\text { ala ng } p a\end{array}$ & g-amoy? & $\begin{array}{l}\text { 16. } \mathrm{Di} \\
\text { tre } \\
\text { Gi } \\
\text { am }\end{array}$ & $\begin{array}{l}\text { Did the patient receive } \\
\text { reatment for the anosmia? } \\
\text { Ginamot ba ang pagkawala ng pang- } \\
\text { imoy ng pasyente? }\end{array}$ \\
\hline $\begin{array}{l}\square \text { Active (Aktibo) } \\
\square \text { Recovered (G } \\
\square \text { Deceased (Pun }\end{array}$ & umaling & & $\begin{array}{l}\square \text { Yes }(O o) \\
\square \text { No (Hindi) }\end{array}$ & & & & $\begin{array}{l}\square \text { Yes } \\
\square \text { No }\end{array}$ & $\begin{array}{l}\mathbf{s}(O o) \\
(\text { Hindi) }\end{array}$ \\
\hline $\begin{array}{l}\text { 17. Comments } \\
\text { Iba pang impo } \\
\end{array}$ & Additic & onal informat & & & & & & \\
\hline
\end{tabular}

Figure 1. AAO-HNS COVID-19 Anosmia Reporting Tool (bilingual adaptation). Reproduced and used with permission from: AAO-HNS Anosmia Team

of 22.7 to as high as $85.6 \%{ }^{4,7-8}$ These reports support the inclusion of anosmia as part of the constellation of symptoms of COVID-19 infection.

In the current study, more than $95 \%$ of patients who presented with anosmia had a positive COVID-19 RT-PCR test result. Taking into consideration the likelihood of getting a positive COVID-19 RT-PCR 


\section{ORIGINAL ARTICLES}

test result for patients who present with anosmia, it appears that the prevalence is high, with a risk for COVID-19 infection being two times higher than those without anosmia. This suggests that anosmia is highly associated with a positive COVID-19 RT-PCR test result and may be a strong predictor of COVID-19 infection.

Anosmia was the first symptom reported by more than $60 \%$ of patients in this study. In contrast, only $11.8,27$, and $35.5 \%$ of patients had anosmia as the initial presenting symptom reported in the studies of Kaye, Lechien, and Beltran-Corbellini, respectively., ${ }^{4,6}$, Other symptoms included fever, cough, rhinorrhea, nasal congestion, malaise/fatigue, and dyspnea. When it comes to symptoms frequently associated with anosmia, our results were similar to those of Wee and colleagues which revealed fever as the most common, followed by cough, and rhinorrhea. ${ }^{8}$

In the study by Kaye, only $27 \%$ of patients with anosmia noted improvement within a mean time of 7.2 days while majority (85\%) noted improvement within 10 days. ${ }^{6}$ However, the diagnosis of some patients was only presumed and not confirmed. Lechien and colleagues noted olfactory dysfunction related to COVID-19 in 85.6\% of their sample population - $79.6 \%$ of which were anosmic and $20.4 \%$ were hyposmic. ${ }^{4}$ Early olfaction recovery rate was noted in $44 \%$ while olfactory function was recovered in $72.6 \%$ of cases, occurring within 8 days upon resolution of the disease. Anosmia persisted even after resolution of other symptoms in $63 \%$ of cases. ${ }^{4}$ In the present study, anosmia resolved in 38 (60.3\%) patients while 25 (39.7\%) claimed to have persistence of loss of smell. Almost three quarters of patients in the present study reported that their symptoms worsened after the onset of anosmia, early in the disease timeline. It would be worthwhile to monitor and follow up the course of anosmia of each patient.

The exact mechanism of how SARS-CoV-2, the etiologic agent for COVID-19, inflicts olfactory dysfunction is yet to be elucidated but a theory posits that direct extension through the nasal mucosa and to the olfactory bulb contributes to the neuroepithelial dysfunction brought about by this virus. ${ }^{4-6,9}$ The virus appears to have an affinity for angiotensin-converting enzyme 2 (ACE2) receptors which are abundant in goblet and ciliated cells in the nasal and respiratory tract epithelium, and sustentacular and basal cells in close proximity with olfactory receptors cells. ${ }^{4-6,9,11}$ These are viable theories underlying anosmia in COVID-19 infection with more avenues and facets remaining to be explored. This adds to the list of viruses that affect nerves in the otolaryngologic domain such as herpes zoster oticus, Ramsay hunt syndrome, and Bell's palsy to name a few.

Our study has certain limitations. A full physical and endoscopic examination of the patients was not performed to exclude anatomical or other conditions which may cause anosmia apart from nasal problems listed as exclusion criteria. Participants did not undergo objective tests to evaluate olfactory function and confirm the subjective reports of anosmia. Such tests were made more difficult by existing protocols to minimize exposure and avoid close contact to prevent further spread of infection. The study used a cross-sectional design, hence, disease progression from the participants' point of entry in the study until resolution of the condition were not monitored and documented. In addition, since participants were asked to look back at the preceding events in their history, certain details may not be recalled clearly.

We recommend that anosmia be included in local COVID-19 symptom checklists and that it be utilized or considered as a screening symptom in various screening tools, such as health declaration forms. A nationwide, multicenter study on anosmia related to COVID-19 infection may be undertaken to better characterize its onset, relation and course.

In conclusion, our study showed that anosmia was associated with a positive SARS-CoV-2 (COVID-19) RT-PCR test in more than $95 \%$ of those who reported the symptom. Anosmia should be considered as a red flag sign which should be included in the screening of persons suspected of being infected with COVID-19 to help mitigate further spread of the virus.

\section{REFERENCES}

1. COVID-19 Dashboard by the Center for Systems Science and Engineering at Johns Hopkins University [lnternet]. Johns Hopkins University \& Medicine. [updated 2020 Sept 29; cited 2020 Sept 29]. Available from: https://coronavirus.jhu.edu/map.html.

2. WHO Coronavirus Disease (COVID-19) Dashboard [Internet]. World Health Organization. [updated 2020 Sept 16; cited 2020 Sept 16]. Available from: https://covid19.who.int.

3. COVID-19 Tracker: Philippines [Internet]. Republic of the Philippines Department of Health [updated 2020 Sept 29; cited 2020 Sept 29]. Available from: https://www.doh.gov.ph/ covid19tracker.

4. Lechien JR, Chiesa-Estomba CM, De Siati DR, Horoi M, Le Bon SD, Rodriguez A, et al. Olfactory and gustatory dysfunctions as a clinical presentation of mild-to-moderate forms of the coronavirus disease (COVID-19): a multicenter European study. Eur Arch Otorhinolaryngol. 2020 Aug;277(8):2251-2261. DOI:10.1007/s00405-020-05965-1 PubMed PMID: 32253535 PubMed Central PMCID: PMC7134551.

5. Lechien J, Cabaraux P, Chiesa-Estomba C, Khalife M, Plzak J, Hans S, et al. Objective olfactory testing in patients presenting with sudden onset olfactory dysfunction as the first manifestation of confirmed COVID-19 infection. medRxiv. 2020 Apr 18 [cited 2020 Sept 16]. Available from: https://doi.org/10.1101/2020.04.15.20066472.

6. Kaye R, Chang CWD, Kazahaya K, Brereton J, Denneny JC. COVID-19 anosmia reporting tool: initial findings. Otolaryngol Head Neck Surg. 2020 Jul 1;163(1):132-134. DOI: 10.1177/0194599820922992 PubMed PMID: 32340555.

7. Menni C, Valdes AM, Freidin MB, Sudre CH, Nguyen LH, Drew DA, et al. Real-time tracking of self-reported symptoms to predict potential COVID-19. Nat Med. $2020 \mathrm{Jul} ; 26(7): 1037-1040$. DOI: 10.1038/s41591-020-0916-2. Epub 2020 May 11. PubMed PMID: 32393804; PubMed Central PMCID: PMC7751267.

8. Wee LE, Chan YFZ, Teo NWY, Cherng BPZ, Thien SW, Wong HM, et al. The role of self-reported olfactory and gustatory dysfunction as a screening criterion for suspected COVID-19. Eur Arch Otorhinolaryngol. 2020 Apr 24:1-2. [cited 2020 Sept 16]. Available from: http://doi.org/10.1007/ s00405-020-05999-5. PubMed PMID: 32328771 PubMed Central PMCID: PMC7180656.

9. Tong JY, Wong A, Zhu D, Fastenberg JH, Tham T. The prevalence of olfactory and gustatory dysfunction in COVID-19 patients: a systematic review and meta-analysis. Otolaryngol Head Neck Surg 2020 Jul;163(1):3-11. DOI: 10.1177/0194599820926473 PubMed PMID: 32369429.

10. Beltran-Corbellini A, Chico-Garcia JL, Martinez-Poles J, Rodriguez-Jorge F, Natera-Villalba E, Gomez-Corral J, et al. Acute-onset smell and taste disorders in the context of COVID-19: a pilot multicenter polymerase chain reaction based case-control study. Eur J Neurol. 2020 Sep;27(9):1738-1741. DOI: 10.1111/ene.14273. PubMed PMID: 32320508 PubMed Central PMCID: PMC7264557.

11. Lechner M, Chandrasekharan D, Jumani K, Liu J, Gane S, Lund VJ, Philpott C, Jayaraj S. Anosmia as a presenting symptom of SARS-CoV-2 infection in healthcare workers - A systematic review of the literature, case series, and recommendations for clinical assessment and management. Rhinology. 2020 Aug 1;58(4):394-399. DOI: 10.4193/Rhin20.189 PubMed PMID: 32386285 